\title{
DETERMINATION OF DOWNY AND POWDERY MILDEW RESISTANCE OF SOME VITIS SPP.
}

\section{DETERMINAÇÃO DA RESISTÊNCIA AO MÍLDIO E OÍDIO DE ALGUMAS VITIS SPP.}

\author{
Zeynep Yıldırım ${ }^{1}$, Arif Atak ${ }^{2}$, Murat Akkurt ${ }^{1 *}$ \\ ${ }^{1}$ Ankara University Faculty of Agriculture Department of Horticulture Diskapi-Ankara, Turkey \\ ${ }^{2}$ Atatürk Horticulture Central Research Institute, Viticulture; Yalova, Turkey \\ *corresponding author: Murat Akkurt, Tel: +90 530 5601252, e mail: akkurt@agri.ankara.edu.tr
}

(Received 10.05.2018. Accepted 09.04.2019)

SUMMARY

The Black Sea region of Turkey receives an annual rainfall of 2000-2500 $\mathrm{mm}$ and viticulture in the region depends on the rainfall limits significantly. In this study, the resistance of eighty different Vitis species and cultivars/genotypes to downy and powdery mildew was assessed using Marker Assisted Selection coupled with inoculation observations. Six Simple Sequence Repeats (SSR) and one Sequence Characterized Amplified Region (SCAR) markers were developed for different resistance loci (Run1, Rpv1, Ren1, Rpv3, Ren3) from different Vitis genetic resources. Eight of the cultivars/genotypes were characterised as resistant to downy mildew, seven were resistant to powdery mildew, and four were resistant to both diseases. These results, taken together with the disease inoculation observations, revealed 'Köfteci Üzümü' (Vitis labrusca) and 'Giresun 3' (Vitis labrusca) were the most resistant cultivars/genotypes.

\section{RESUMO}

A região do Mar Negro na Turquia apresenta uma precipitação anual de 2000-2500 mm, sendo a viticultura na região muito limitada pela precipitação. Neste estudo, a resistência ao míldio e oídio foi avaliada em oitenta diferentes espécies e cultivares/genótipos de Vitis através da Seleção Assistida por marcadores moleculares, juntamente com observações de inoculação no fenótipo. Foram usados seis microssatélites (SSR) e um marcador de Região Amplificada Caracterizada por Seqüência (SCAR) desenvolvidos para diferentes loci de resistência (Run1, Rpv1, Ren1, Rpv3, Ren3), a partir de diferentes recursos genéticos de Vitis. Oito cultivares / genótipos foram caracterizadas como resistentes ao oídio, sete ao míldio e quatro a ambas as doenças. Estes resultados avaliados em conjunto com as observações de inoculação da doença, revelaram que os cultivares/genótipos 'Köfteci Üzümü' (Vitis labrusca) e 'Giresun 3' (Vitis labrusca) foram os mais resistentes.

Key words: Fungal Diseases, Grapevine, Resistant Loci, Inoculation. Palavras-chave: Doenças fúngicas, Videira, Loci resistentes, Inoculação.

\section{INTRODUCTION}

Grapes are one of the most important fruits in the world and are believed to have been cultivated in different regions globally for thousands of years (Santos et al., 2014). It is widely known that Turkey is an important centre of origin both for cultivated Vitis vinifera ssp. sativa and wild Vitis vinifera ssp. sylvestris (Arroyo-Garcia et al., 2006; Karataş et al., 2014). Grapes are grown in a large area but over time many pests and diseases have begun to affect yield and quality in the world's vineyards. Powdery [Erysiphe necator Schwein. (syn. Uncinula necator (Schw.) (Burr.)] and downy mildew [Plasmopara viticola (Berk. and Curtis) Berl. and de Toni] are the two most significant diseases that devastate grapes worldwide (Wan et al., 2007).

Downy mildew (DM) and powdery mildew (PM) diseases affect grape production and reduce yield in many regions of the world (Jermini et al., 2010; Karbalai-Khiavi et al., 2012; Figueiredo et al., 2017). The incidence of PM has increased in recent years. Climatic conditions and reduced efficacy of fungicides were suggested as possible reasons for this increase (Staudt, 1997; Yildırım et al., 2002; Dean and Gray, 2008). Oliveira and Cunha (2015) reported

This is an Open Access article distributed under the terms of the Creative Commons Attribution License (http://creativecommons.org/licenses/by/4.0), which permits unrestricted use, distribution, and reproduction in any medium, provided the original work is properly cited. 
that diversity of these pathogens also can affect disease resistance of Vitis spp.

These two fungal diseases also cause severe losses in yield and quality in vineyards, particularly in warm and humid climate areas. These two diseases particularly affect leaf, fruit and shoots, leading to significant crop losses. In addition to cultural practices, intensive fungicide applications are used to prevent these diseases. However, according to research in recent years, pesticide residues have negative effects on both human health and the environment (Nicolopoulou-Stamati et al., 2016).

One of the most effective ways to control disease is to develop new cultivars which are resistant to the diseases (Akkurt et al., 2007; Y1ldırım and Dardeniz, 2010; Özer et al., 2012). Production of grape cultivars with high quality that are simultaneously resistant to fungal diseases is one of the most crucial goals of grape breeding (Töpfer et al., 2011; Rex et al., 2014).

Therefore, breeding studies have been performed in different world regions since the early 20th century. In recent years, different resistant genomic regions and associated markers were obtained for these diseases (Dalbó et al., 2001; Welter et al., 2007; Zini et al., 2015).

Grapevines (Vitis vinifera L.) in European viticulture is threatened by pathogens like PM and DM, requiring heavy fungicide applications. Resistance traits from wild Vitis species are introgressed into the cultivated susceptible $V$. vinifera. Molecular markers linked to traits of interest help to accelerate the process, rationalizing the choice of parental types and replacing part of the phenotypic evaluation with genetic testing in the early stages of plant growth (Rex et al., 2014).

Combining resistance gene regions from American wild Vitis species, with good wine qualities of Vitis vinifera $\mathrm{L}$. has become an important strategy for grapevine breeding. Muscadinia rotundifolia was described as totally resistant to PM species. Muscadine is seen as a potential source for disease resistance for $V$. vinifera. One gene that has drawn some attention is the Resistance Uncinula necator 1 gene (Run1), which is the grapevine PM resistance gene. Three molecular markers were confirmed as good candidates for Run1 marker assisted selection (Pauquet et al., 2001; Dry et al., 2010). Eibach et al. (2007) recommend selection using phenotypic data and molecular markers to identify resistance to PM and DM. Gene pyramiding was used to combine Run1 with Ren1, which is another PM resistant gene found in a $V$. vinifera cultivar, and it was confirmed in a $V$. rotundifolia $x V$. vinifera $\mathrm{BC} 5$ hybrid family (Katula-Debreceni et al., 2010).

Grapes of Eurasian origin were believed to be susceptible to American native pathogens like PM and DM. This assumption was explained by the geographical isolation of host and pathogen during their evolution. However, certain East Asian grape species, for example Vitis piasezkii, were found to be at least partly resistant to PM (Pap et al., 2016). It was also reported that some Vitis vinifera cultivars, such as Kismish vatkana and Dzhandzhal Kara which grow in central Asia, are resistant to PM (Hoffmann et al., 2008; Kozma et al., 2014). The resistant loci originating from these varieties is named Ren1 (Resistant to Erysphe necator 1).

The regent cultivar, which is resistant to downy and PM obtained from one of these breeding studies, has begun to be widely grown in Germany (Eibach and Töpfer 2003). Regent carries the dominant resistance genes of Ren3 (Resistant to Erysphe necator 3) and Rpv3 (Resistant to Plasmopara viticola 3). Due to resistance to these diseases, Regent was used as parent in many breeding and QTL studies (Eibach et al., 2007; Van Heerden et al., 2014).

In this study, the resistance of some grape cultivars or genotypes from different origins to DM and PM was observed over two years and also examined with different markers related to resistance to these diseases.

\section{MATERIAL AND METHODS}

\section{Plant Materials}

80 cultivars/genotypes considered to be resistant/tolerant to fungal diseases collected from the humid regions of Turkey (mainly Northern part of Turkey) and different part of the world (mainly Northern part of the United States) were used in this study. Some of these cultivars have been obtained as a result of the breeding program in Turkey, USA and Germany. Information from cultivars/genotypes used in the study are given in Table I. Collected grape cultivars/genotypes were grown in Yalova Atatürk Horticultural Central Research Institute greenhouses. Disease infections and inoculations were carried out in a greenhouse using 2-year-old potted vines grown in 5-litre pots and filled with soil mixture (1/3 garden soil, $1 / 3$ peat moss, and $1 / 3$ blended compost). Also optimum climatic conditions $\left(22-25{ }^{\circ} \mathrm{C}\right.$ and $80 \%$ Relative humidity) were ensured for the development of diseases in the greenhouse. 


\section{TABLE I}

The origin of cultivars/genotypes and inoculation results (N: No band associated with resistance allele; ER:Extremely Resistant, HR:Highly Resistant, R:Resistant, S:Susceptible and HS:Highly Susceptible after inoculation).

Origem das cultivares / genótipos e resultados de inoculação ( $N$ : Sem banda associada ao alelo de resistência; ER: Extremamente resistente, HR: Altamente resistente, R: Resistente, S: Susceptivel e HS: Altamente susceptivel após a inoculação)

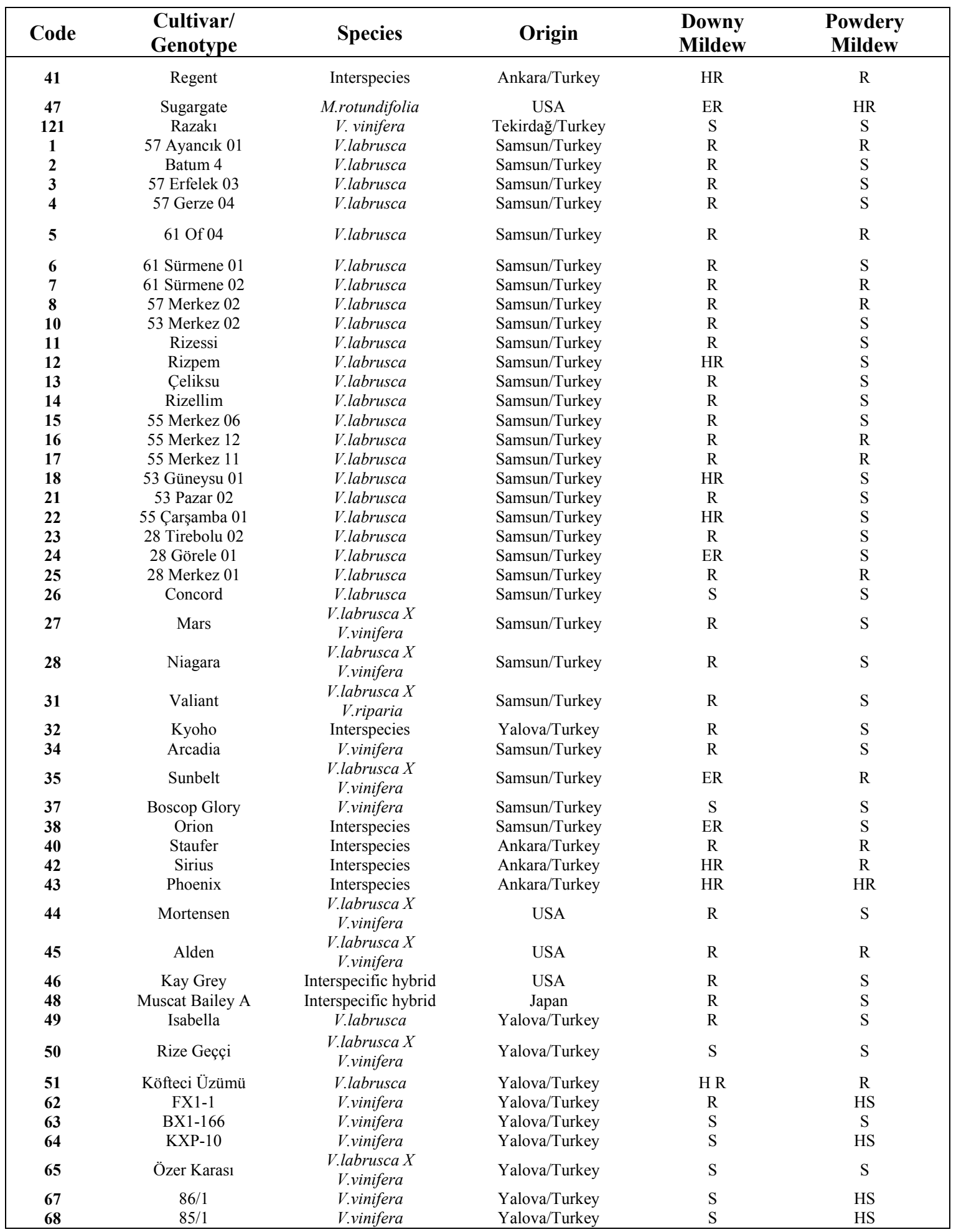


TABLE I (continuation)

The origin of cultivars/genotypes and inoculation results (N: No band associated with resistance allele; ER:Extremely Resistant, HR:Highly Resistant, R:Resistant, S:Susceptible and HS:Highly Susceptible after inoculation).

Origem das cultivares / genótipos e resultados de inoculação ( $N$ : Sem banda associada ao alelo de resistência; ER: Extremamente resistente, HR: Altamente resistente, R: Resistente, S: Susceptivel e HS: Altamente susceptivel após a inoculação)

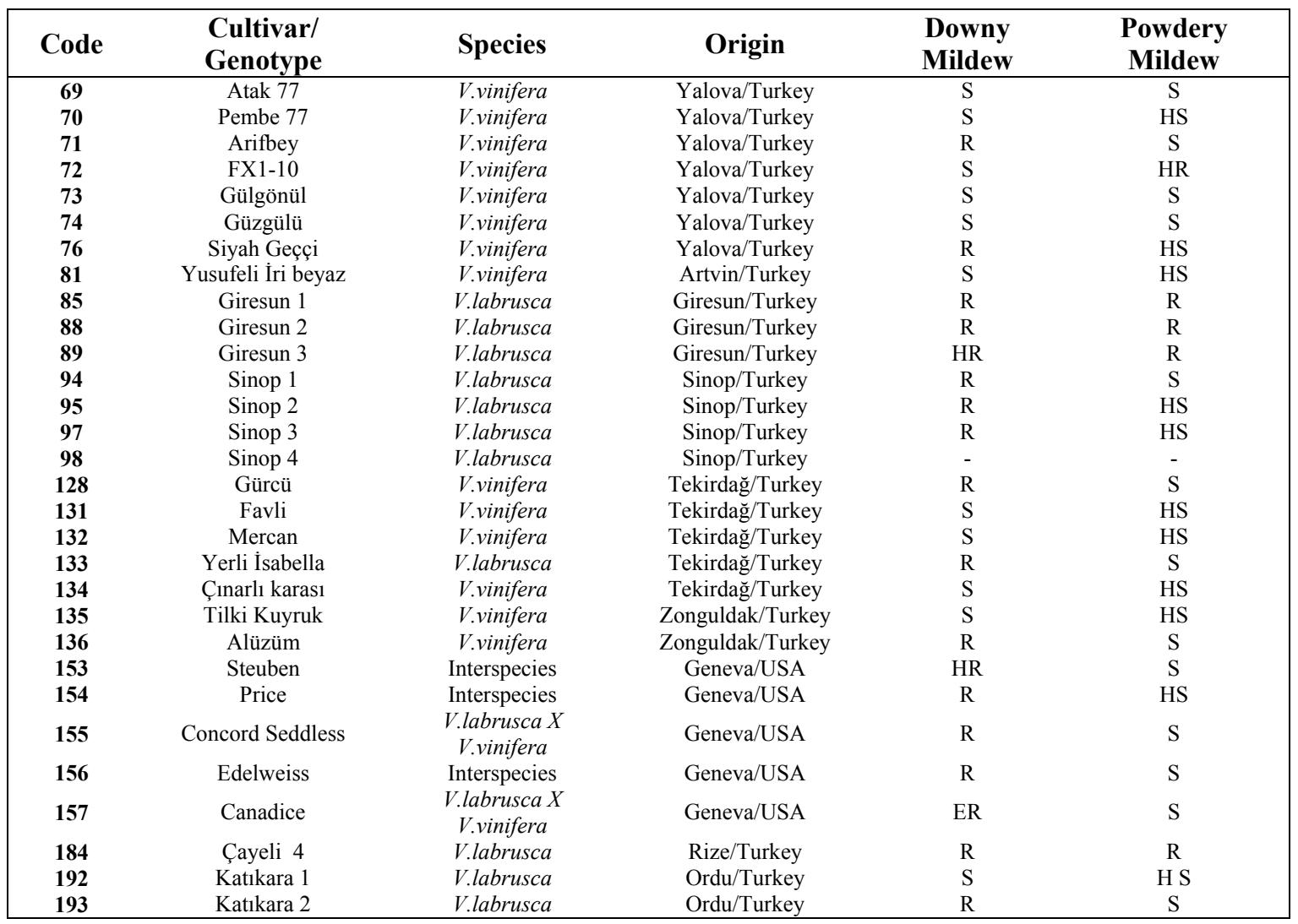

DNA isolation, PCR reactions and fragment analyses were conducted at Molecular Genetic Laboratories of Ankara University, Faculty of Agriculture, Department of Horticulture. The present investigation was carried out during the production period of the years 2014-15 and 2015-16.

\section{Inoculation for DM}

The method of Rumbolz et al. (2002) and Boso et al. (2006) were used to propagate sporangia inoculum. Plasmopara viticola was obtained from naturally infected plants in the vineyards of the Atatürk Horticulture Central Research Institute Yalova, Turkey. Plants were sprayed with a suspension of sporangia (40,000 sporangia $\mathrm{ml}^{-1}$ distilled water) on the abaxial leaf side and whole plants were covered with a polyethylene cover during the night. On following day, the polyethylene covers were removed and incubation lasted 5-6 days at $25-26^{\circ} \mathrm{C}$. The same inoculation procedure was repeated after 5-6 days in order to provide a better infection.

\section{Inoculation for PM}

The modified method of Wang et al. (1995) was applied for inoculation of plants with PM. Briefly, fungal conidia were collected from naturally infected leaves from the vineyard, washed with $78 \%$ glucose solution, imitating the osmotic pressure of PM conidia and then suspended in sterile water. Vine leaves were inoculated with the conidial suspension at the rate of $2 \times 10^{5}$ sporangia $\mathrm{ml}^{-1}$ by spraying the upper surface of the leaves. Inoculated leaves were immediately covered by thin plastic for 6 hours. 


\section{Evaluation of inoculated leaves}

For disease evaluation, four young leaves from each genotype or cultivar were arbitrarily selected for resistance evaluation for each disease. The symptoms on each leaf were rated from 0 to 7 , based on the estimated percentage of lesion over the whole leaf as follows (Wan et al., 2007): Grade $0=$ no symptoms, 1 $=0.1-5.0 \%, 2=5.1-15.0 \%, 3=15.1-30.0 \%, 4=$ $30.1-45.0 \%, 5=45.1-65.0 \%, 6=65.1-85.0 \%, 7=$ $85.1-100.0 \%$. The grades were then converted into a susceptibility index (SI). Disease severity was evaluated 3 weeks after inoculation.

$\mathrm{SI}=\{[$ Sum of (Grade value $\mathrm{x}$ number of leaves in that grade)] / (Total leaf number $\mathrm{x}$ Highest grade value) $\} \times 100$

DM and PM resistance levels of each genotype were rated in five categories based on its SI value: $\mathrm{SI}=0$ extremely resistant (ER). SI $=0-5$ highly resistant
(HR). $\mathrm{SI}=5.1-25$ resistant $(\mathrm{R}) . \mathrm{SI}=25.1-50$ susceptible (S). SI $=50.1-100$ highly susceptible (HS).

\section{DNA extraction}

Young leaves were collected and immediately frozen at deep freeze. DNA extraction was carried out using the method of Norgen Biotek Plant/Fungi Isolation Kit (Norgen Biotek Corporation, Canada). The DNA quality analysed with both methods; gel electrophoresis and spectrophotometer (NanoDrop ND-1000 Spectrohotometer, Wilmington, DE, USA).

\section{PCR Analyses}

Six SSR markers; VMC8g9, VMC4f3.1, VMC1g3.2, UDV020a, VMC9h4.2, VMC7f2 and SCAR marker SCORA7 were used for PCR analyses. Markers used in the study and related references are shown on Table II.

TABLE II

Markers used in the study

Marcadores utilizados no estudo

\begin{tabular}{|c|c|c|c|c|c|}
\hline $\begin{array}{l}\text { Marker } \\
\text { Name }\end{array}$ & 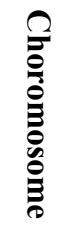 & 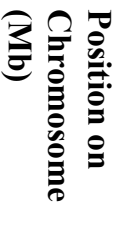 & $\begin{array}{l}\text { Forward } \\
\text { primer }\end{array}$ & $\begin{array}{r}\text { Reverse } \\
\text { Primer }\end{array}$ & Reference \\
\hline VMC8g9 & 12 & 20.4 & $\begin{array}{l}\text { AACATTATCAACAACA } \\
\text { TGGTTTTA }\end{array}$ & $\begin{array}{l}\text { ATATTCATCCTTCCCA } \\
\text { TCACTA }\end{array}$ & Barker et al. (2005) \\
\hline VMC4f3.1 & 12 & 13.1 & $\begin{array}{l}\text { AAAGCACTATGGTGG } \\
\text { GTGTAAA }\end{array}$ & $\begin{array}{l}\text { TAACCAATACATGCAT } \\
\text { CAAGGA }\end{array}$ & Barker et al. (2005) \\
\hline UDV-020a & 13 & & $\begin{array}{l}\text { TGTTGGTGTGTGTTTG } \\
\text { TACGTG }\end{array}$ & $\begin{array}{l}\text { TGTTGGCCTGATGTTG } \\
\text { AGAG }\end{array}$ & Hoffmann et al. (2008) \\
\hline VMC9h4.2 & 13 & 18.4 & $\begin{array}{l}\text { GCAGTTGATGCAAAA } \\
\text { CAACAGT }\end{array}$ & $\begin{array}{l}\text { CACATCATTCATTGAT } \\
\text { GAGGCT }\end{array}$ & Hoffmann et al. (2008) \\
\hline ScORA7 & 15 & - & $\begin{array}{l}\text { GAAACGGGTGTGAGG } \\
\text { CAAAGGTGG }\end{array}$ & $\begin{array}{l}\text { GGCCATTAGGAAATCA } \\
\text { ACATTAC }\end{array}$ & Akkurt et. al. (2007) \\
\hline VMC1g3.2 & 12 & 10.0 & $\begin{array}{l}\text { GATAGTTACCATACTT } \\
\text { AGTCGGA }\end{array}$ & $\begin{array}{l}\text { ACTTAGCTTCAGAAGA } \\
\text { AAATAGA }\end{array}$ & Merdinoglu et al. (2003) \\
\hline VMC7f2 & 18 & 26.9 & $\begin{array}{l}\text { TCCGACTTTGGGTAAT } \\
\text { AAGC }\end{array}$ & $\begin{array}{l}\text { AAGATGACAATAGCG } \\
\text { AGAGAGAA }\end{array}$ & Bellin et al. (2009) \\
\hline
\end{tabular}

PCR reactions for six SSR loci were performed in a reaction volume of $10 \mu \mathrm{l}$ containing $15 \mathrm{ng}$ of DNA, 5 pmol of each forward and reverse primer, $0.5 \mathrm{mM}$ dNTP, 0.5 unit GoTaq DNA Polymerase (Promega, Madison, WI) that includes $1.5 \mathrm{mM} \mathrm{MgCl}_{2}$.
Amplifications were performed on a Biometra Uno Thermocycler (Biometra, Göttingen, Germany) with the following cycling conditions; initial denaturation step $3 \mathrm{~min}$ at $94^{\circ} \mathrm{C}$, followed by 35 cycles of denaturation at $1 \mathrm{~min}$ at $94^{\circ} \mathrm{C}$, annealing $1 \mathrm{~min}$ at 50 - 
$60^{\circ} \mathrm{C}$ (depending on each primer pair-specific annealing temperature) and $2 \mathrm{~min}$ at $72^{\circ} \mathrm{C}$ with a final extension $10 \mathrm{~min}$ at $72^{\circ} \mathrm{C}$. For SCAR marker PCR assays were performed in standard assays in a total volume of $20 \mu$ l containing $0.25 \mathrm{mM}$ of each dNTP, $0.25 \mu \mathrm{M}$ of each primer, $0.5 \mathrm{U}$ Taq DNA polymerase, $1.5 \mathrm{mM} \mathrm{MgCl}_{2}$, and 20-40 ng template DNA. The PCR conditions were as follows: an initial cycle of 3 min at $95^{\circ} \mathrm{C}$, followed by 30 cycles of denaturation at $1 \mathrm{~min}$ at $95^{\circ} \mathrm{C}$ in, annealing for $1 \mathrm{~min}$ at $60^{\circ} \mathrm{C}$, a synthesis step $2 \mathrm{~min}$ at $72^{\circ} \mathrm{C}$, and final extension 10 min at $72^{\circ} \mathrm{C}$.

PCR products from SSR and SCAR markers were checked by gel electrophoresis (1.5-2 \% agarose) under UV light. Fragment size of PCR products obtained by SSR technique was determined by Fragment Analyser (Advanced Analytical Technologies, Inc. IS, USA). PCR products were analysed according to the Fragment Analyser protocol. Allele size of the obtained peak images were determined by ProSize software.

In each PCR run, Regent (Interspecies hybrid) and Sugargate $(M$. rotundifolia) were included as the reference cultivars because of the presence of disease resistance loci. Razakı ( $V$. vinifera $\mathrm{cv}$.) was used as negative control.

\section{RESULTS AND DISCUSSION}

In Turkey, there is a noticeable variety of climates, with considerable differences between the areas, and also with some microclimates due to exposure on slopes and coasts. The north of Turkey is quite rainy, but has relatively warm and humid regions. Turkey is one of the most important countries for vineyard areas and grape production. Due to ideal climatic conditions and suitable growing circumstances, Turkey has very rich Vitis germplasm. The northern part of Turkey, especially, has some fungal disease resistant/tolerant genotypes. A large part of the material was collected from this region. These cultivars/genotypes grow in a very humid ecology. They predominantly consist of $V$. labrusca and V.labrusca $x$ V.vinifera hybrids.

In this study, fungal disease tolerant/resistant cultivars/genotypes which were collected from humid regions (mainly from Turkey) had disease resistance level determined with molecular markers and also artificial inoculations.

Eighty cultivars/genotypes were analysed using the seven markers considered responsible for DM and PM resistance. Allele sizes of cultivars/genotypes were compared with Regent (interspecies hybrid, complex resistance against DM and PM) and Sugargate $(M$. rotundifolia), both presenting a high degree of tolerance to DM and PM.

Six SSR primers (VMC8g9, VMC4f3.1, VMC1g3.2, UDV20a, VMC9h4, VMC7f2) and one SCAR primer (SCORA7) were used in association with the Run1, Rpv1, Ren1 and Rpv3 resistance genes for markerassisted selection. VMC8g9, VMC4f3.1, UDV020a, VMC9h4.2 and SCORA7 markers were used for determination of PM resistance. VMC1g3.2 and $\mathrm{VMC} 7 \mathrm{f} 2$ markers were used for determination of DM resistance (Table II).

The resistance loci against PM (Run1) is a single dominant gene present in Muscadinia rotundifolia, but absent in Vitis vinifera species. This resistant locus was introgressed successfully from Muscadinia rotundifolia into $V$. vinifera using a pseudo-backcross strategy (Barker et al., 2005). Several genetic markers that are linked to the resistance locus were previously identified by researchers. VMC8g9, VMC4f3.1 and GLP1-12 were successfully used to identify PM resistant genotypes (Marguerit et al., 2009; KatulaDebreceni et al., 2010; Agurto et al., 2017).

VMC8g9 and VMC4f3.1 markers were used to determine PM resistance associated with the resistance gene Run1. Molnar et al. (2007) used the same markers and they found $186 \mathrm{bp}$ allele size for VMC4f3.1 and $160 \mathrm{bp}$ allele size for VMC8g9 in resistant individuals in the M.rotundifolia X V.vinifera hybrid population. In our study, no genotype presented a 186 or 160 bp allele size. This result may have occurred because our genotypes did not originate from M.rotundifolia. Most of the genotypes used in our study were V.labrusca and the natural hybrid of V.labrusca $X$ V.vinifera so we could not detect any Run1 positive genotypes. However, Kozma et al. (2009) reported that VMC4f3.1 and VMC8g9 markers could be used to identify resistant individuals in their population. They developed new hybrids that are resistant to PM in their project. These hybrids were developed from Kishmish vatkana $\mathrm{BC} 3$ and $\mathrm{BC} 4$ hybrids and $V$. amurensis $\mathrm{X} V$. vinifera hybrids.

VMC1g3.2 marker was described as an Rpv1associated marker by Wiedemann-Merdinoglu (2003). With this marker, we obtained allele size of between 132-274 bp. A large number of cultivars/genotypes were found to have the same band sizes (140 and/or $153 \mathrm{bp}$ ) as the control cultivars (Regent and Sugargate) in our study. KatulaDebreceni et al. (2010) identified the allel size of the VMC1g3.2 marker associated with the Rpv1 gene as $122 \mathrm{bp}$. Cultivars/genotypes used in our study did not show alleles related to resistance. 
The resistance gene observed in cultivated plants of Vitis vinifera is called Ren1. Ren1 was first determined by Hoffman et al. (2008) in 'Kishmish vatkana' and 'Dzhandzhal kara' which are cultivated in Central Asia since the 1920s. As a result of Hoffmann et al. (2008), individuals with a size of $161 \mathrm{bp}$ allele for the UDV020a marker and those individuals with VMC9h4.2 marker size of 283 bp allele were associated with Ren1. Ren 1 was detected on chromosome 13, unlike the resistance genes previously found in wild North American grapes and their interspecific hybrids (Coleman et al., 2009). In our study, we tested both markers in relation to Ren 1 . When fragment sizes obtained from the VMC9h4.2 marker were examined, in our study, six cultivars/genotypes were identified as having $283 \mathrm{bp}$ alleles (Table III). Contrary to expectations, inoculation results indicate that these cultivars/genotypes were susceptible to PM; however, they were resistant to DM. In case of UDV020 marker, genotype 98 (Sinop 4/V. labrusca) showed an allele size of $161 \mathrm{bp}$ and was selected as a resistant candidate genotype (Table III).

\section{TABLE III}

Markers used in the study and resistant candidate genotypes after MAS

Marcadores utilizados no estudo e genótipos candidatos resistentes após Seleção Assistida por Marcador

\begin{tabular}{|c|c|c|c|c|c|}
\hline Marker & $\begin{array}{l}\text { Associated } \\
\text { gene }\end{array}$ & Resistance origin & $\begin{array}{l}\text { Resistant-Associated } \\
\text { allele size (bp) }\end{array}$ & $\begin{array}{l}\text { Resistant- } \\
\text { Candidate } \\
\text { Genotypes }\end{array}$ & $\begin{array}{l}\text { Determined } \\
\text { allele size (bp) }\end{array}$ \\
\hline VMC8g9 & Run1 & M. rotundifolia & 160 & - & - \\
\hline VMC4f3.1 & Run1 & M. rotundifolia & 186 & - & - \\
\hline VMC1g3.2 & Run1 & M. rotundifolia & 122 & - & - \\
\hline UDV020a & Ren1 & Kishmish vatkana & 161 & 98 (Sinop 4) & $158 / 161$ \\
\hline \multirow[t]{6}{*}{ VMC9h4 } & Ren1 & Kishmish vatkana & 283 & 12 (Rizpem) & $283 / 292$ \\
\hline & & & & 14 (Rizellim) & $283 / 292$ \\
\hline & & & & 26 (Concord) & $283 / 292$ \\
\hline & & & & 27 (Mars) & $272 / 283$ \\
\hline & & & & 31 (Valiant) & $283 / 283$ \\
\hline & & & & 32 (Kyoho) & $283 / 290$ \\
\hline VMC7F2 & Run2.1 & M. rotundifolia & 193 & - & - \\
\hline \multirow[t]{4}{*}{ VMC7F2 } & Rpv3 & Bianca & - & 4 (57 Gerze 04$)$ & $210 / 216$ \\
\hline & & & & 38 (Orion) & $210 / 216$ \\
\hline & & & & 40 (Staufer) & $210 / 216$ \\
\hline & & & & 44 (Mortensen) & $210 / 216$ \\
\hline \multirow[t]{9}{*}{ SCORA7 } & Ren3 & Regent & 760 & $\begin{array}{l}51 \text { (Köfteci Üzümü) } \\
2 \text { (Batum 4) }\end{array}$ & $\begin{array}{l}210 / 216 \\
760\end{array}$ \\
\hline & & & & 17 (55 Merkez 11) & 760 \\
\hline & & & & 37 (Boscop Glory) & 760 \\
\hline & & & & 38 (Orion) & 760 \\
\hline & & & & 40 (Staufer) & 760 \\
\hline & & & & 42 (Sirius) & 760 \\
\hline & & & & 43 (Phoenix) & 760 \\
\hline & & & & 47 (Sugargate) & 760 \\
\hline & & & & 184 (Rize Çayeli 4) & 760 \\
\hline
\end{tabular}

Akkurt et al. (2007) developed SCAR markers associated with Ren3 resistant loci to Uncinula necator from QTL regions of Regent $\mathrm{x}$ Lemberger hybrids. The SCORA7 marker was determined to be 
useful in marker-assisted selection for resistance to powdery mildew and also later referred to as a Ren3associated marker in different publications (Eibach et al., 2007; Van Heerden et al., 2014). When the results obtained from the SCORA7 marker were examined, the fragment of $760 \mathrm{bp}$ associated with resistance was obtained in 10 cultivars/genotypes including Regent and Sugargate (Table III). Also, when we evaluated the results from our disease scores, some of these genotypes have this band even though they are susceptible. These are Batum 4 ( $V$. labrusca), Orion (interspecies hybrid) and Boscop Glory (V.vinifera). The other seven cultivars/genotypes were found to be resistant or very resistant in accordance with the SCORA7 marker (Table III).

The VMC7f2 marker was analysed in our population and we obtained an allele size of between $210 \mathrm{bp}$ and 222 bp. Forty-six cultivars/genotypes showed the same allele sizes for at least one locus of Regent or Sugargate. Also, 5 of these cultivars/genotypes were found to have the same for both alleles (210 bp and 216 bp) compared with Regent (Table III). These 5 genotypes, which have the same allele as Regent, were found to be mildew resistant in inoculation test results. Bellin et al. (2009) reported that in the genetic map of 'Bianca' $x$ 'Chardonnay' hybrid population, the VMC7f2 marker is closely related to the Rpv3 gene. 'Bianca' is heterozygous for a dominant gene, located in a $2.9 \mathrm{cM}$ interval at the Rpv3 locus on chromosome 18. 'Villard Blanc' is in the pedigree of 'Bianca' and 'Regent' and it is also a common parent. It is claimed that the downy mildew resistance locus was transferred to 'Bianca' from 'Villard Blanc' (Bellin et al., 2009). This case explains the presence of downy mildew resistant genotypes bearing the VMC7f2 marker and Regent alleles. Riaz et al. (2011) studied VMC7f2 marker for $M$. rotundifolia cv. Mognolia and they reported that it was associated with the Run2.1 gene which is responsible for PM resistance on chromosome 18. The researchers detected Run2.1 allele associated with resistance at 193 bp locus. In our study, no cultivar/genotypes which have 193 bp allele related to Muscadinia origin resistance locus were found.

Several studies reported that some cultivars or genotypes may be resistant to both PM and DM diseases. Kozma and Dula (2003) studied interspecies hybrids and they reported that some hybrids resistant to PM may also be resistant to DM. They also associated double disease resistance with the Run1 gene. Similarly, Merdinoglu et al. (2003) used 208 SSR, 13 ISSR and 151 RAPD markers in order to find markers which are associated with resistance to DM in Muscadinia cultivars. They strongly suggested that the identified QTL corresponds to a unique major gene conditioning DM resistance in the Muscadine grapes, which was named Rpv1. Moreover, Rpv1 was shown to be tightly linked to the dominant gene conferring resistance to PM, Run1. Similarly, in this study, it was found that especially few $V$. labrusca and interspecific hybrid cultivars/genotypes were resistant to both diseases. It was observed that $V$. labrusca and interspecies cultivars or genotypes are significantly more resistant to both diseases than V.vinifera especially in the species-specific evaluation. This was more pronounced for PM disease (Table I).

In this study, eighty cultivars/genotypes were studied with 7 different markers and also PM and DM inoculations were applied over two years. When cultivars/genotypes were evaluated, a total of 204 bands were obtained with at least one locus size the same compared with the control cultivars (Regent and Sugargate). Also 24 cultivars/genotypes have the same locus size for both alleles compared with Regent or Sugargate.

One of the $V$. labrusca genotypes with the code number 94, which gave the same band sizes as Regent for 4 markers, attracted attention. However, according to the results of disease inoculations, this genotype was found to be resistant to DM but sensitive to PM. Nevertheless, when the disease inoculation and molecular analysis results of the study are evaluated together, the results were compatible with each other.

Cultivars/genotypes of $V$. labrusca and interspecies have more gene regions which are associated with disease resistance compared to $V$. vinifera cultivars/genotypes. Especially after evaluation of both diseases, $V$. labrusca and interspecific hybrids were determined to be more resistant. It is clear that it would be appropriate to use $V$. labrusca and interspecific hybrids as parents in resistance breeding programs in the future.

When these results evaluated together with inoculation observations; especially 'Köfteci Üzümü' (a possible Vitis labrusca genotype) and 'Giresun 3' (a possible Vitis labrusca genotype) were selected as the most resistant cultivars/genotypes (Table I and III). Although no resistance locus could be detected in 'Giresun 3' genotype, inoculation observations indicated high resistance to both diseases.

\section{CONCLUSIONS}

In this study, it was determined the resistance of powdery and downy mildew diseases of cultivars/genotypes collected from different humid regions with marker assisted selection and disease 
inoculations. The results of the study indicate that the genotypes that belong to V.labrusca species are highly has shown to be resistant to diseases. In particular, the resistance to downy mildew disease was higher.

Local genotypes of 'Köfteci üzümü' and 'Gerze 04' were selected as the most resistant genotypes after marker assisted selection and inoculation test. While the genotypes 'Sinop 4', 'Rizpem' and 'Rizellim' revelled resistance to powdery mildew with molecular markers they not presented resistance in inoculation tests. The genotype of 'Giresun 3' was found highly resistant to both diseases as a result of inoculation tests, however as a result of selection by molecular markers, it was not found to be related to resistance to diseases.

\section{REFERENCES}

Agurto M., Schlechter R.O., Armijo G., Solano E., Serrano C., Contreras R.A., Zúñiga G.E., Arce-Johnson P., 2017. RUN1 and REN1 Pyramiding in Grapevine (Vitis vinifera cv. Crimson Seedless) Displays an Improved Defense Response Leading to Enhanced Resistance to Powdery Mildew (Erysiphe necator). Front Plant Sci., 8, 758

Arroyo-García R., Ruiz-García L., Bolling L., Ocete R., López M.A., Arnold C., Ergul A., Söylemezoğlu G., Uzun H.I., Cabello F., Ibáñez J., Aradhya M.K., Atanassov A., Atanassov I., Balint S., Cenis J.L., Costantini L., Goris-Lavets S., Grando M.S., Klein B.Y., McGovern P.E., Merdinoglu D., Pejic I., Pelsy F., Primikirios N., Risovannaya V., Roubelakis-Angelakis K.A., Snoussi H., Sotiri P., Tamhankar S., This P., Troshin L., Malpica J.M., Lefort F., Martinez-Zapater J.M., 2006. Multiple origins of cultivated grapevine (Vitis vinifera L. ssp. sativa) based on chloroplast DNA polymorphisms. Mol. Ecol., 15(12), 3707-3714.

Akkurt M., Welter L., Maul E., Töpfer R., Zyprian E., 2007. Development of SCAR markers linked to powdery mildew (Uncinula necator) resistance in grapevine (Vitis vinifera $\mathrm{L}$. and Vitis sp.). Mol Breed., 19, 103-111.

Barker C.L., Donald T., Pauquet J., Ratnaparkhe M.B., Bouquet A., Adam-Blondon A.F., Thomas M.R., Dry I., 2005. Genetic and physical mapping of the grapevine powdery mildew resistance gene, RUN1, using a bacterial artificial chromosome library. Theor Appl Genet., 111, 370-377.

Bellin D., Peresotti E., Merdinoglu D., Wiedemann-Merdionoglu S., Adam-Blondon A.F., Cipriani G., Morgante M., Testolin R., Di Gaspero G., 2009. Resistance to Plasmopara viticola in grapevine 'Bianca' is controlled by a major dominant gene causing localised necrosis at the infection site. Theor Appl Genet., 120, 163-176.

Boso S., Martinez M.C., Unger S., Kassemeyer H.H., 2006. Evaluation of foliar resistance to downy mildew in different cv. Albariño clones. Vitis, 45, 23-27.

Coleman C., Copetti D., Cipriani G., Hoffmann S., Kozma P., Kovács L., Morgante M., Testolin R., Di Gaspero G., 2009. The powdery mildew resistance gene REN1 co-segregates with an NBS-LRR gene cluster in two Central Asian grapevines. BMC Genet., 10, 89 .
According to these results obtained, marker-assisted selection and disease inoculation tests should be applied together in disease-resistant breeding programs for different Vitis spp. In addition, cultivars/genotypes belonging to the $V$. labrusca species, which are resistant to fungal diseases, can be used in breeding programs to transfer resistance characteristics to the new high-quality cultivars. Thus, much more environmentally- friendly cultivars can be obtained.

\section{ACKNOWLEDGMENTS}

This research was funded by the National Scientific and Technological Research Council of Turkey (Grant No.1130641). Turkey.

Dalbo M.A., Ye G.N., Weeden N.F., Wilcox W.F., Reisch B.I., 2001. Marker-assisted selection for powdery mildew resistance in grapes. J. Am. Soc. Hortic. Sci., 126, 83-89.

Dean A., Gray G., 2008. Powdery mildew diseases, Oregon State University Extension. Plant Disease Control, 101, 121-126.

Dry I.B., Feechan A., Anderson C., Jermakow A. M., Bouquet A., Adam-Blondon A. F., Thomas M.R., 2010. Molecular strategies to enhance the genetic resistance of grapevines to powdery mildew. Aust. Jj Grape Wine R., 16, 94-105.

Eibach R., Zyprian E.M., Welter L.J., Topfer R. 2007. The use of molecular markers for pyramiding resistance genes in grapevine breeding. Vitis, 46, 120-124.

Figueiredo A., Martins J., Sebastiana M., Guerreiro A., Silva A. Matos A.R., Monteiro F., Pais M.S., Roepstorff P., Coelho A.V., 2017. Specific adjustments in grapevine leaf proteome discriminating resistant and susceptible grapevine genotypes to Plasmopara viticola. J. Proteomics, 152, 48-57.

Hoffmann S., Di Gaspero G., Kovács L , Howard S., Kiss E., Galbács Z., Testolin R., Kozma P., 2008. Resistance to Erysiphe necator in the grapevine 'Kishmish vatkana' is controlled by a single locus through restriction of hyphal growth. Theor Appl Genet., 116, 427-438.

Jermini M., Blaise P., Gessler C., 2010. Quantitative effect of leaf damage caused by downy mildew (Plasmopara viticola) on growth and yield quality of grapevine 'Merlot' (Vitis vinifera). Vitis, 49, 7785

Karataş D.D., Karataş H., Laucou V., Sarıkamıș G., Riahi L. Bacilieri R., This P., 2014. Genetic diversity of wild and cultivated grapevine accessions from southeast Turkey. Hereditas 151, 73-80.

Katula-Debreceni D., Lencsés A.K., Szoke A., Veres A., Hoffmann S., Kozma P., Kovács L.G., Heszky L. Kiss E., 2010. Markerassisted selection for two dominant powdery mildew resistance genes introgressed into a hybrid grape population. Sci Horti., 126, 448-453.

Kozma P., Dula T., 2003. Inheritance of resistance to downy mildew and powdery mildew of hybrid familiy Muscadinia $\mathrm{x} V$. vinifera $\mathrm{x} V$. amurensis $\mathrm{x}$ Franco-American hybrid. Proc. VIIIth Int'l. Congress on Grape. Acta Hortic., 603, 457-463. 
Kozma P., Kiss E. Hoffmann S., Galbacs Z. Tula T., 2009. Using the powdery mildew resistant Muscadinia rotundifolia and Vitis vinifera 'Kishmish vatkana' for breeding new cultivars. Acta Hortic., 827, 559-564.

Kozma P., Hoffmann S., Cindric P., 2014. New generation of resistant table grape cultivars. Acta Hortic., 1046, 41-48.

Marguerit E., Boury C., Manicki A., Donnart M., Butterlin G., Némorin A., Wiedemann- Merdinoglu S., Merdinoglu D., Ollat N., Decroocq S., 2009. Genetic dissection of sex determinism, inflorescence morphology and downy mildew resistance in grapevine. Theor. and Appl. Genetics, 118, 1261-1278.

Merdinoglu D., Wiedeman-Merdinoglu S., Coste P., Dumas V., Haetty S., Butterlin G., Greif C., Adam-Blondon A.F., Fouquet A., Pauquet J. 2003. Genetic analysis of downy mildew resistance derived from Muscadinia rotundifolia. Acta Hortic., 603, 451-456.

Molnár S., Galbács Z., Halász G., Hoffmann S., Kiss E., Kozma P., Veres A., Galli Z., Szöke A. Heszky, L., 2007. Marker assisted selection (MAS) for powdery mildew resistance in a grapevine hybrid family. Vitis, 46, 212-213.

Nicolopoulou-Stamati P., Maipas S., Kotampasi C., Stamatis P., Hens L., 2016. Chemical pesticides and human health: The urgent need for a new concept in agriculture. Front Public Health, 4, 148.

Oliveira M., Cunha M., 2015. Study of the Portuguese populations of powdery mildew fungus from diverse grapevine cultivars (Vitis vinifera). OENO One, 49, 173-182.

Özer C., Solak E., Öztürk L., Özer N., 2012. The development of powdery mildew tolerant grape cultivars with standard quality characteristics by crossbreeding. Afr. J. Agric. Res., 7, 1374-1380.

Pap D., Riaz S., Dry I.B., Jermakow A., Tenscher A.C., Cantu D., Olah R., Walker A.A., 2016. Identification of two novel powdery mildew resistance loci, Ren6 and Ren7, from the wild Chinese grape species Vitis piasezkii. BMC Plant Biol., Jul 29, 16(1), 170.

Reisch B.I., Pratt, C., 1996. Grapes. In, J. Janick, J. N. Moore (Eds). Fruit breeding. Vine and small fruit crops, Vol. 2, 197-369, Wiley, New York.

Rex M., Welter L.J., Töpfer R., Zyprian E., 2014. Dissecting the genetic determinants of powdery mildew resistance in grape. Acta Hortic., 1046, 79-84.

Riaz S., Tenscher A.C., Ramming D.W., Walker M.A., 2011. Using a limited mapping strategy to identify major QTLs for resistance to grapevine powdery mildew (Erysiphe necator) and their use in marker-assisted breeding. Theor Appl Genet., 122, 1059-1073.
Rumbolz J., Wirtz S., Kassemeyer H.H., Guggenheim R., Schäfer E., Büche, C., 2002. Sporulation of Plasmopara viticola, differentiation and light regulation. Plant Biol., 4, 413-422.

Santos S., Oliveira M., Amorim A., Van Asch B., 2014. A forensic perspective on the genetic identification of grapevine (Vitis vinifera L.) varieties using STR markers. Electrophoresis, 35, 2122.

Staudt G., 1997. Evaluation of grapevine powdery mildew (Uncinula necator, anamorph Oidium tuckeri) in accessions of Vitis species. Vitis, 36, 151-154.

Töpfer R., Hausmann L., Harst M., Maul E., Zyprian E., Eibach R., 2011. New horizons for grapevine breeding. Fruit, Veg. Cereal Sci. Biotech., 5 (Sepcial Issue), 79-100.

Van Heerden C.J., Burger P., Vermeulen A., Prins R. 2014. Detection of downy and powdery mildew resistance QTL in a 'Regent' × 'Red Globe' population. Euphytica, 200, 281-295.

Wang Y., Liu H., Chen J., Lamikanra O., Lu J., 1995. Evaluation of resistance to Uncinula necator in Chinese wild Vitis species. Vitis, 34, 159-164.

Wan Y., Schwaniniger H., He P., Wang, Y., 2007. Comparison of resistance to powdery mildew and downy mildew in Chinese wild grapes. Vitis, 46,132-136.

Welter L.J., Göktürk-Baydar N., Akkurt M., Maul E., Eibach R., Töpfer R., Zyprian E.M., 2007. Genetic mapping and localization of quantitative trait loci affecting fungal disease resistance and leaf morphology in grapevine (Vitis vinifera L). Mol Breeding 20, 359374.

Wiedemann-Merdinoglu S., Prado E., Coste P., Dumas V., Butterlin G., Bouquet A., Merdinoglu D., 2006. Genetic analysis of resistance to downy mildew from Muscadinia rotundifolia. In: 9th International Conference Grape Genetic and Breeding Udine, Italy.

Yıldırım D., Onoğur E., Irshad M., 2002. Investigations on the efficacy of some natural chemicals against powdery mildew [Uncinula necator (Schw.) Burr.] of grape. J Fitopatologi., 150, 697-702.

Y1ldırım D., Dardeniz A., 2010. Effects of alternative spray programs and various combinations of green pruning on powdery mildew [Uncinula necator (Schw.) Burr.] in Karasakız (Kuntra) grape cultivar. Turk J Agric For., 34, 213- 223.

Zini E., Raffeiner M., Di Gaspero G., Eibach R., Grando M.S., Letschka T., 2015. Applying a defined set of molecular markers to improve selection of resistant grapevine accessions. Acta Hortic. 1082, 73-78. 